\title{
MODEL ANALISIS PENGARUH CITRA MEREK DAN HARGA TERHADAP KEPUTUSAN PEMBELIAN XIAOMI SMARTPHONE
}

\section{THE INFLUENCE MODEL OF THE EFFECT OF BRAND IMAGE AND PRICES ON XIAOMI SMARTPHONES' PURCHASE DECISIONS}

\author{
Silvia Sari Sitompul \\ Sekolah Tinggi Ilmu Ekonomi Pelita Indonesia \\ silviasari.sitompul@yahoo.co.id
}

Submit, 11-04-2019 Accepted, 20-06-2019 Publish, 23-06-2019

\begin{abstract}
Mobile is not only used to communicate via telephone or sms, but consumers want more so that mobile features are increasingly diverse. Since the internet began to boom in Indonesia, the Internet has become a mandatory feature and has turned into a function in the cellphone itself besides being used for telephone and sms. So it is not surprising that cellphones with the lowest prices must fulfill three conditions, which can be used for telephone, SMS, and the internet. Our people are very thirsty for browsing, chatting, playing games and also for work. The internet has also become a basic necessity for every individual, because with the internet, humans have a lot of information. The internet is also useful for business, politics, economics and socializing.The purpose of this study is to find out and analyze the influence of Brand Image and prices on the purchase decision of Xiaomi Smartphone. The method used is multiple linear regression analysiswith a sample of 100 respondents. The research results show that the prices effect significant on Consumer decisions on Xiaomi Smartphone while brand image does not have aeffect significant on Consumer decisions on Xiaomi Smartphone
\end{abstract} Keywords: Brand Image, Features, Prices

\begin{abstract}
ABSTRAK
Handphone tidak hanya digunakan untuk berkomunikasi via telepon atau sms, namun konsumen menginginkan lebih sehingga fitur ponsel pun semakin beragam. Sejak internet mulai booming di indonesia, Internet menjadi fitur yang wajib ada dan berubah menjadi fungsi dalam ponsel itu sendiri selain digunakan untuk telepon dan sms. Maka tak heran bila ponsel dengan harga paling murah wajib memenuhi tiga syarat yaitu dapat digunakan untuk telepon,SMS, dan internet.Masyarakat kita sangat haus akan browsing, chatting, bermain game dan juga untuk bekerja. Internet juga sudah menjadi kebutuhan pokok bagi setiap individu, karena dengan adanya internet, manusia memiliki banyak informasi. Internet juga bermanfaat untuk berbisnis, politik, ekonomi dan bersosialisasi.Tujuan penelitian ini yaitu Untuk Mengetahui dan menganalisis pengaruh Citra Merek dan harga terhadap keputusan pembelian Xiaomi Smartphone. Metode yang digunakan adalah analisis regresi linier berganda.dengan jumlah sampel 100 responden. Hasil Penelitian menunjukkan bahwa Harga berpengaruh signifikan terhadap keputusan Konsumen pada Xiaomi Smartphone sedangkan Citra merek tidak berpengaruh signifikan terhadap keputusan Konsumen
\end{abstract}

Kata Kunci : Citra Merek, Harga 
PENDAHULUAN

Handphone tidak hanya digunakan untuk berkomunikasi via telepon atau sms, namun konsumen menginginkan lebih sehingga fitur ponsel pun semakin beragam. Sejak internet mulai booming di indonesia, Internet menjadi fitur yang wajib ada dan berubah menjadi fungsi dalam ponsel itu sendiri selain digunakan untuk telepon dan sms. Maka tak heran bila ponsel dengan harga paling murah wajib memenuhi tiga syarat yaitu dapat digunakan untuk telepon, SMS, dan internet.Masyarakat kita sangat haus akan browsing, chatting, bermain game dan juga untuk bekerja. Internet juga sudah menjadi kebutuhan pokok bagi setiap individu, karena dengan adanya internet, manusia memiliki banyak informasi. Internet juga bermanfaat untuk berbisnis, politik, ekonomi dan bersosialisasi. Melalui internet banyak sarana yang menyediakan berbagai informasi.

Tabel 1.

Marketshare Smartphone 2015-2017

\begin{tabular}{cccc}
\hline Vendor & $\mathbf{2 0 1 5}$ & $\mathbf{2 0 1 6}$ & $\mathbf{2 0 1 7}$ \\
\hline Samsung & $30,4 \%$ & $28,8 \%$ & $31,8 \%$ \\
\hline Oppo & $13,1 \%$ & $16,6 \%$ & $20,1 \%$ \\
\hline Xiaomi & $5,1 \%$ & $7,7 \%$ & $10,5 \%$ \\
\hline Asus & $4,7 \%$ & $6,8 \%$ & $6,5 \%$ \\
\hline Lenovo & $4,2 \%$ & $5,6 \%$ & $6,0 \%$ \\
\hline Others & $42,4 \%$ & $34,4 \%$ & $25,1 \%$ \\
\hline Total & $100 \%$ & $100 \%$ & $100 \%$ \\
\hline
\end{tabular}

Sumber: IDC 2018

Dilihat dari Tabel 1. diatas pada data market share tahun 2015 sebesar $5,1 \%$, tahun 2016 sebesar 7,7\% dan pada tahun 2017 sebesar $10,5 \%$. xiaomi berada di urutan ketiga dengan penjualan yang terus meningkat setiap tahunnya. Merek Xiaomi juga turut bersaing dengan merek unggulan smartphone lainnya seperti Samsung, Oppo, Asus, Lenovo dan lainnya. Hal ini akan mempengaruhi konsumen dalam memutuskan pembelian smartphone.

Salah satu smartphone yang memiliki kemampuan tinggi adalah Xiaomi. Sebagai salah satu perusahaan swasta yang baru berdiri dari tahun 2010, perusahaan ini bergerak di bidang teknologi dengan produk unggulan nya berupa smartphone. Ini adalah sebuah terobosan baru bagi Xiaomi karena melihat perkembangan zaman yang semakin canggih dan peluang yang ada di dalam dunia smartphone terutama di wilayah Asia yang memiliki pangsa pasar potensial. Xiaomi Smartphone adalah sebuah perangkat atau produk teknologi berupa telepon genggam atau mobile versi modern terbaru yang memiliki kelebihan dimana spesifikasi software dan hardware lebih pintar, fungsi yang lebih cerdas, dan fitur-fitur yang lebih pintar dari ponsel versi biasa sebelumnya. Alasan memilih perusahaan Xiaomi Smartphone sebagai tempat untuk melakukan penelitian karena Xiaomi Smartphone adalah suatu produk yang baru saja muncul di Indonesia. Persaingan didunia teknologi yang semakin lama kian menarik dan Xiaomi Smartphone salah satu pabrikan handphone yang namanya sudah mulai dikenal dikalangan masyarakat.

Asia Ponsel Pekanbaru merupakan salah satu perusahaan yang menjual Smartphone Xiaomi yang berlokasi di Pekanbaru. Asia Ponsel Pekanbaru belum memiliki strategi yang tepat sehingga menyebabkan volume penjualan yang didapat belum maksimal. Untuk melihat tingkat penjualan pada produk Smartphone Xiaomi Pekanbaru maka disajikan data penjualan Asia Ponsel Pekanbaru selama 3 tahun terakhir. 
Tabel 2

Data Penjualan Smartphone pada Asia Ponsel Pekanbaru

\begin{tabular}{ccccccc}
\hline \multirow{2}{*}{ Merk } & \multicolumn{2}{c}{2015} & \multicolumn{2}{c}{2016} & \multicolumn{2}{c}{2017} \\
\cline { 2 - 7 } Smartphone & $\mathrm{T}$ & $\mathrm{R}$ & $\mathrm{T}$ & $\mathrm{R}$ & $\mathrm{T}$ & $\mathrm{R}$ \\
\hline Samsung & 250 & 375 & 325 & 403 & 500 & 715 \\
\hline Vivo & 200 & 252 & 285 & 335 & 400 & 510 \\
\hline Oppo & 150 & 223 & 270 & 297 & 300 & 483 \\
\hline Xiaomi & 80 & 106 & 150 & 142 & 200 & 227 \\
\hline
\end{tabular}

Sumber : Asia Ponsel Pekanbaru

Dilihat dari Tabel 2 diatas pada data penjualan Asia Ponsel Pekanbaru selalu mengalami peningkatan dari tahun 2015-2017 dimana samsung mendominasi penjualan tertinggi diikuti oleh vivo, oppo dan xiaomi yang ikut turut bersaing dalam beberapa merek smartphone yang dijual pada asia ponsel. Dimana dari data diatas penjualan xiaomi terus meningkat setiap tahunnya, akan tetapi realisasi pada tahun 2016 tidak tercapai dari target yang sudah ditetapkan.

Dari tabel tersebut dapat dilihat bahwa xiaomi masih kalah bersaing dengan kompetitor smartphone lainnya, asia ponsel harus menerapkan strategi pemasaran yang efektif untuk meningkatkan penjualan xiaomi dengan memberikan informasi produk lebih baik lagi kepada konsumen yang akan membelinya. Pentingnya keputusan pembelian bagi perusahaan sendiri sangat berarti untuk mempertahankan kelangsungan hidup bisnis tersebut dalam jangka panjang. tentunya ketiga aspek tersebut sangat berperan penting untuk konsumen dalam memutuskan keputusan pembelian. Citra merek yang baik dibenak konsumen harus ada, fitur yang canggih dan juga harga yang terjangkau membuat konsumen tertarik dan melakukan pembelian secara berulang yang mengakibatkan omset penjualan pada xiaomi mengalami peningkatan lebih baik lagi.

Berdasarkan pada uraian dan fenomena tersebut diatas, menunjukkan terdapat suatu masalah yang timbul dalam keputusan pembelian terhadap keputusan Xiaomi Smartphone Pada Asia Ponsel Pekanbaru, sehingga menjadi sesuatu hal yang menarik untuk dilakukan penelitian dengan mengambil judul "Model analisis pengaruh citra merk dan harga terhadap keputusan pembelian xiaomi smartphone pada asia ponsel pekanbaru".

Menurut Kotler \& Keller (2009) proses pengambilan keputusan pembelian melewati lima tahap yaitu pengenalan masalah, pencarian informasi,evaluasi alternatif,keputusan pembelian,perilaku pasca pembelian.. Citra merek merupakan persepsi masyarakat terhadap perusahaan atau produknya. Citra dapat terbentuk melalui rangsangan yang datang dari luar sebagai suatu pesan yang menyentuh atau yang disebut informasi yang diterima seseorang. Kotler dan Keller (2009), harga merupakan elemen dari bauran pemasaran yang dihasilkan berupa pendapatan, elemen lain menghasilkan biaya. Harga adalah elemen termudah dari sebuah program pemasaran untuk disesuaikan, fitur produk, saluran, dan bahkan komunikasi membutuhkan banyak waktu.

Adapun tujuan dalam penelitian ini adalah sebagai berikut : (1) Untuk Mengetahui dan menganalisis pengaruh citra merekterhadap keputusan Keputusan Pembelian Xiaomi Smartphone Pada Asia Ponsel Pekanbaru (2) Untuk Mengetahui dan menganalisis pengaruh Harga terhadap keputusan Keputusan Pembelian Xiaomi Smartphone Pada Asia Ponsel Pekanbaru

Dalam dunia bisnis selalu ada kompetisi antar perusahaan. Perusahaan akan terus berusaha untuk memperluas pasar dan mempertahankan eksistsensi perusahaan. Aktivitas perusahaan dalam pemasaran ini untuk menentukan arah 
perusahaan agar mampu bersaing dalam dunia persaingan yang semakin ketat. Pemasaran merupakan unsur penting dalam perusahaan untuk menentukan sukses tidaknya suatu bisnis. Untuk itu perusahaan harus menerapkan pengertian pemasaran dengan benar agar terus dapat tetap bertahan dalam persaingan bisnis.

Pemasaran adalah suatu sistem total dari kegiatan bisnis yang dirancang untuk merencanakan, menentukan harga, promosi dan mendistribusikan barang-barang yang dapat memuaskan keinginan dan mencapai pasar sasaran serta tujuan perusahaan. Menurut Kotler dan Amstrong. (2008) "Pemasaran adalah mengidentifikasi dan memenuhi kebutuhan manusia dan sosial. Memenuhi kebutuhan dengan cara menguntungkan". Menurut Buchari Alma (2009) Pemasaran adalah proses manajemen untuk mengidentifikasikan, mengantisipasi, dan memuaskan pelanggan secara menguntungkan.

Merek merupakan janji penjual untuk secara konsisten memberikan feature, manfaat, dan jasa tertentu kepada pembeli, bukan hanya sekedar simbol yang membedakan produk perusahaan tertentu dengan kompetitornya . Kotler dan Amstrong (2008) mempunyai pendapat bahwa merek merupakan nama, istilah, tanda, simbol, desain atau kombinasi yang ditujukan untuk mengidentifikasi barang atau jasa yang ditawarkan perusahaan sekaligus sebagai diferensiasi produk.

Dari uraian definisi diatas dapat disimpulkan bahwa merek adalah nama, istilah, tanda, simbol atau desain dari produk atau jasa atau kombinasi keseluruhan yang dimaksud untuk mengidentifikasi barang dan jasa dari seseorang atau kelompok penjual dan untuk membedakan dari produk pesaing. Merek juga dapat meninggalkan citra dan pengalaman dibenak konsumen mengenai keuntungan dari produk yang diproduksi dari perusahaan.

Ada dua langkah utama dalam membangun brand yang kuat, pertama dimulai dengan membangun value position dan kedua adalah build the brand. Langkah pertama lebih kepada positioning atau yang lebih tepat lagi adalah differentiation. Langkah kedua melibatkan pemilihan nama brand, menumbuhkan asosiasi dengan nama brand, dan yang terakhir adalah mengelola semua kontak antara brand dengan pelanggan sehingga image dari brand tersebut diterima secara konsisten dan memenuhi customer expectations.

Menurut Davidson, et, al., (2010) citra merk terdiri dari : (1) Nama Baik (Reputation), tingkat atau status yang cukup tinggi dari sebuah merek produk tertentu. (2) Pengenalan (Recognition), yaitu tingkat dikenalnyal sebuah merek oleh konsumen. Jika sebuah merek tidak dikenal maka produk dengan merek tersebut harus dijual dengan mengandalkan harga yang murah (3) Hubungan Emosional (Affinity), hubungan emosional yang terjadi antar brand dengan pelanggan. Yaitu suatu emotional relationship yang timbul antara sebuah merek dengan konsumennya. Sebuah produk dengan merek yang disukai oleh konsumen akan lebih mudah dijual dan sebuah produk yang dipersepsikan memiliki kualitas yang tinggi akan memiliki reputasi yang baik. (4) Kesetiaan Merek (Brand loyalty), seberapa jauh kesetiaan konsumen menggunakan produk dengan brand tertentu.

Bernadette (2013) Harga merupakan salah satu penentu keberhasilan suatu perusahaan karena harga menentukan seberapa besar keuntungan yang akan diperoleh perusahaan dari penjualan produknya 
baik berupa barang maupun jasa. Harga adalah suatu elemen bauran pemasaran yang menghasilkan pendapatan, elemen lain menghasilkan biaya. Harga merupakan elemen termudah dalam program pemasaran untuk disesuaikan, fitur produk, saluran, dan bahkan komunikasi membutuhkan banyak waktu. (Kotler, 2010).

Harga adalah sejumlah uang yang ditagihkan atas suatu produk dan jasa atau jumlah dari nilai yang ditukarkan para pelanggan untuk memperoleh manfaat dari memiliki atau menggunakan suatu produk dan jasa. (Kotler dan amstrong, 2008). Harga merupakan komponen yang berpengaruh langsung terhadap laba perusahaan. tingkat harga yang ditetapkan mempengaruhi kuantitas yang terjual. Selain itu secara tidak langsung harga juga mempengaruhi biaya, karena kuantitas yang terjual berpengaruh pada biaya yang ditimbulkan dalam kaitannya dengan efisiensi produksi. Untuk pelanggan yang sensitif terhadap harga, harga yang murah biasanya adalah sumber kepuasan yang penting karena pelanggan akan mendapatkan value for money yang tinggi (Wibowo, 2012). Dari sudut pandang konsumen, harga sering kali digunakan sebagai indikator nilai bilamana harga tersebut dihubungkan dengan manfaat yang dirasakan atas suatu barang atau jasa. (Guntur, 2010). Metode penetapan harga menurut Tjiptono (2010) secara garis besar dapat dikelompokan menjadi empat kategori utama, yaitu metode penetapan harga berbasis permintaan, berbasis biaya, berbasis laba, dan berbasis persaingan.

Dimensi harga produk menurut Stanton (2008) yaitu:(1) Keterjangkauan harga, sejauh mana sesuatu yang terjangkau, yang diukur dengan biaya relative terhadap jumlah yang membeli mampu membayar. (2) Kesesuaian harga dengan kualitas produk, keseimbangan antara harga produk yang ditawarkan dengan kualitas produk yang diterima. (3) Daya saing harga, kekuatan harga yang ditawarkan dalam pemasaran suatu produk.(4) Kesesuaian harga dengan manfaat, keseimbangan antara harga produk ditawarkan dengan manfaat yang diterima oleh konsumen.

Keputusan pembelian merupakan sikap seseorang untuk membeli atau menggunakan suatu produk baik berupa barang atau jasa yang telah diyakini akan memuaskan dirinya dan kesediaan menanggung resiko yang mungkin ditimbulkannya. Keputusan pembelian yang diambil oleh pembeli sebenarnya merupakan kumpulan dari sejumlah keputusan yang terorganisir (Adirama 2012).

Adapun indikator keputusan pembelian terdiri dari : (1) Masalah, (2) Pencarian Informasi, (3)Evaluasi Alternatif, (4)Keputusan Pembelian, (5)Perilaku Pasca Pembelian (Kotler dan Amstrong, 2012)

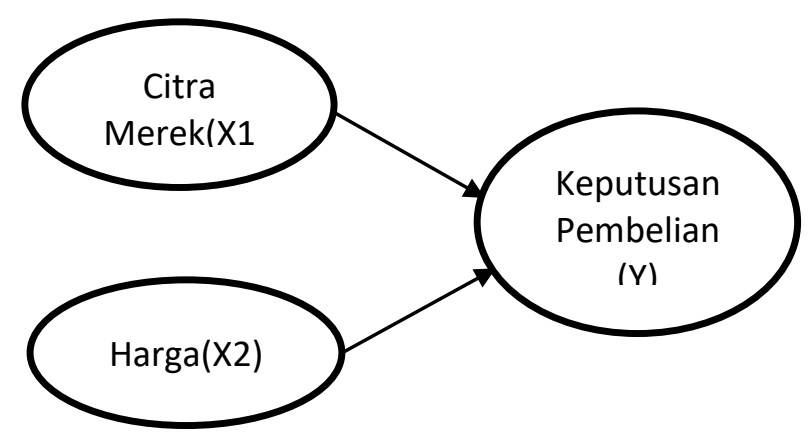

Sumber: Data Olahan 2018

\section{Gambar 1. Kerangka Pemikiran}

Hipotesis merupakan jawaban sementara terhadap rumusan masalah. Karena sifatnya yang sementara, maka perlu dibuktikan kebenarannya melalui data yang terkumpul. Berdasarkan latar belakang permasalahan dan kerangka pemikiran yang telah diuraikan 
sebelumnya, maka hipotesis dalam penelitian ini adalah: (1) pengaruh citra merk terhadap keputusan pembelian (2) pengaruh hargaterhadap keputusan pembelian

\section{METODE PENELITIAN Tempat dan Waktu Penelitian}

Penelitian ini dilaksanakan di Asia Ponsel Pekanbaru yang beralamat di Jalan Jendral Sudirman Pekanbaru. Waktu penelitian ini dilakukan pada bulan September 2018 s/d November 2018.

\section{Populasi dan Sampel}

Menurut Sugiyono (2010) populasi adalah wilayah generalisasi yang terdiri atas obyek atau subyek yang mempunyai kualitas dan karakteristik tertentu yang ditetapkan oleh peneliti untuk dipelajari dan kemudian ditarik kesimpulannya. Populasi penelitian ini adalah konsumen yang melakukan pembelian produk Xiaomi Smartphone di Asia Ponsel Pekanbaru. Penelitian ini menggunakan rumus Roscoe dimana ada 3 variabel, yang terdiri dari 2 variabel bebas dan 1 variabel terikat,maka jumlah sampel yang digunakan sebanyak $3 \times 10=30$ orang responden.Tetapi untuk menghindari angket yang tidak lengkap dan untuk menghindari data yang tidak valid maka dalam penelitian ini akan menggunakan sampel sebanyak 100 orang responden.

\section{Teknik Pengumpulan Data}

Teknik pengumpulan data yang digunakan dalam penelitian ini adalah sebagai berikut:

Dokumentasi,merupakan metode pengumpulan data yang dilaukan dengan cara mengcopy data yang sudah di (2) AngketYaitu suatu cara pengumpulan data melalui daftar peryataan yang telah peneliti siapkan yang ditujukan kepada responden yang akan dijadikan sampel. (3) Dokumentasi
Merupakan suatu cara mengumpulkan dokumen-dokumen, serta mencatat data-data yang tersedia yang berhubungan dengan permasalahan penelitian. (4) Wawancara Merupakan suatu cara pengumpulan data yang digunakan oleh peneliti untuk mendapatkan informasi dengan melakukan Tanya jawab secara lisan dan tatap muka dengan responden. Sehingga Instrumen pertanyaan atau pernyataan ini akan menghasilkan total skor bagi tiap anggota sampel yang diwakili oleh setiap nilai skor seperti instrumen dibawah ini : (1) SS = Sangat setuju diberi skor 5. (2) $\mathrm{S}=$ Setuju diberi skor 4. (3) $\mathrm{C}=$ Cukup Setuju diberi skor 3. (4) TS = Tidak setuju diberi skor 2. (5) STS = Sangat tidak setuju diberi skor 1

\section{Metode Analisis Data Uji Validitas dan Uji Reliabilitas}

Uji Validitas digunakan untuk mengukur sah atau tidaknya suatu angket. Suatu angket dikatakan sah jika pernyataan pada angket mampu mengungkapkan sesuatu yang akan diukur oleh angket tersebut. Uji Validitas dilakukan dengan membandingkan nilai $r_{\text {hitung }}$ dengan $r_{\text {tabel }}$ untuk degree of freedom $(d f)=\mathrm{n}-\mathrm{k}$, dalam hal ini $\mathrm{n}$ adalah jumlah sampel dan k adalah jumlah item. Pada program SPSS dapat dilihat pada kolom corrected item-total correlations dengan kriteria sebagai berikut : (1) Jika $r_{\text {hitung }}>r_{\text {tabel }}$, maka pernyataan tersebut dikatakan valid (2) Jika $r_{\text {hitung }}<r_{\text {tabel }}$, maka pernyataan tersebut dikatakan tidak valid.Sedangkan Uji reliabilitas merupakan alat untuk mengukur suatu angket yang merupakan indikator dari variabel atau konstruk. Suatu angket dikatakan reliabel atau handal jika jawaban seseorang terhadap pernyataan konsisten atau stabil dari waktu ke waktu. Program komputer SPSS memberikan fasilitas untuk mengukur 
reliabilitas dengan uji statistik Cronbach Alpha $(\alpha)$. Suatu variabel dikatakan reliabel jika memberikan nilai $\alpha>0,60$

\section{Uji F}

Uji F pada dasarnya menunjukkan apakah semua variabel bebas yang dimasukkan dalam model mempunyai pengaruh secara bersama-sama terhadap variabel terikat. Dalam penelitian ini pengujian hipotesis secara simultan dimaksudkan untuk mengukur besarnya pengaruh Citra Merk dan Harga secara bersama-sama terhadap variabel terikatnya yaitu Keputusan Pembelian.

\section{Uji Koefisien Determinasi (R)}

Koefisien determinasi digunakan untuk menjelaskan proporsi variabel dependen (bebas) yang mampu dijelaskan oleh variasi variabel independennya (terikat). Nilai koefisien determinasi adalah $0<2<1$. Nilai $R^{2}$ yang kecil berarti kemampuan variabel indenpenden hampir memberikan semua informasi yang dibutuhkan untuk memprediksi variabel dependen. Kelemahan mendasar penggunaan koefisien determinasi adalah bias terhadap jumlah variabel dependen yang dimasukkan terhadap model. Oleh karena itu, banyak peneliti menganjurkan nilai adjusted $\mathrm{R}^{2}$ pada model regresi yang terbaik.

\section{Analisis Regresi Linear Berganda}

Dalam upaya menjawab permasalahan dalam penelitian ini maka digunakan analisis regresi linier berganda (Multiple Regression). Analisis regresi berganda adalah hubungan secara linier antara dua atau lebih variabel independen (X1,X2) dengan variabel dependen (Y). Adapun model persamaan yang digunakan dalam penelitian ini adalah sebagai berikut, hipotesis pada Citra Merk dan Harga, terhadap Keputusan Pembelian. $Y=a+\beta_{1} X_{1}+\beta_{2} X_{2}+e$

\section{Uji T}

Uji $\mathrm{t}$ digunakan untuk menguji signifikansi hubungan antara variable $\mathrm{X}$ dan variabel $\mathrm{Y}$, apakah variabel X1, X2, benar-benar berpengaruh secara parsial atau individual terhadap variabel Y.

\section{Definisi Operasional Variabel}

Tabel 3

Definisi Operasional Variabel

\begin{tabular}{|c|c|c|c|}
\hline Variabel & Definisi Variabel & Indikator & Skala \\
\hline $\begin{array}{l}\text { Citra } \\
\text { Merek } \\
(\mathrm{X} 1)\end{array}$ & $\begin{array}{lr}\text { Citra Merek } & \text { adalah } \\
\text { persespsi dan keyakinan } \\
\text { yang dipegang oleh } \\
\text { konsumen, seperti yang } \\
\text { dicerminkan asosiasi yang } \\
\text { tertanam dalam ingat } \\
\text { pelanggan, yang selalu } \\
\text { diingat pertama kali saat } \\
\text { mendengar slogan dan } \\
\text { tertanam dibenak } \\
\text { konsumen. } \\
\text { (Kotler dan Keller, 2009) }\end{array}$ & $\begin{array}{l}\text { 1. Nama Baik } \\
\text { (Reputation) } \\
\text { 2. Pengenalan } \\
\text { (Recognition } \\
\text { ) } \\
\text { 3. Hubungan } \\
\text { Emosional } \\
\text { (Affinity) } \\
\text { 4. Kesetiaan } \\
\text { Merek } \\
\text { (Brand } \\
\text { Loyalty) } \\
\text { (Davidson, } \\
\text { 2010) }\end{array}$ & Interval \\
\hline $\begin{array}{l}\text { Harga } \\
(\text { X2) }\end{array}$ & $\begin{array}{l}\text { Harga adalah sejumlah } \\
\text { uang yang dibebankan atas } \\
\text { suatu produk atas jasa, atau } \\
\text { jumlah dari nilai yang } \\
\text { ditukar konsumen atas } \\
\text { manfaat-manfaat karena } \\
\text { memiliki atau } \\
\text { menggunakan produk atau } \\
\text { jasa tersebut. } \\
\text { (Daryanto, 2013) }\end{array}$ & $\begin{array}{l}\text { 1. Keterjangkau } \\
\text { an Harga } \\
\text { 2. Kesesuaian } \\
\text { Harga } \\
\text { 3. Daya Saing } \\
\text { Harga } \\
\text { (Stanton, 2008) }\end{array}$ & Interval \\
\hline $\begin{array}{l}\text { Keputus } \\
\text { an } \\
\text { Pembeli } \\
\text { an } \\
\text { ( Y ) }\end{array}$ & $\begin{array}{lr}\text { Keputusan } & \text { Pembelian } \\
\text { adalah tidak terpisahkan } \\
\text { dari bagaimana sifat } \\
\text { seorang } & \text { konsumen } \\
\text { (consumer } & \text { behavior) } \\
\text { sehingga } & \text { masing-masing } \\
\text { konsumen } & \text { memiliki } \\
\text { kebiasaan } & \text { yang berbeda } \\
\text { dalam } & \text { melakukan } \\
\text { pembelian. } & \\
\text { Kotler \& Keller }(2012)\end{array}$ & $\begin{array}{l}\text { 1. Pengenalan } \\
\text { Masalah } \\
\text { 2. Pencarian } \\
\text { Informasi } \\
\text { 3. Evaluasi } \\
\text { Alternatif } \\
\text { 4. Keputusan } \\
\text { Pembelian } \\
\text { 5. Perilaku } \\
\text { Pasca } \\
\text { Pembelian } \\
\text { (Kotler dan } \\
\text { Amstrong, } \\
\text { 2012) }\end{array}$ & Interval \\
\hline
\end{tabular}

Sumber: Data Olahan 2018

\section{HASIL DAN PEMBAHASAN}

Karakteristik Responden

Penelitian ini menggunakan analisis regresi linear berganda, alat analisis yang digunakan adalah IBM SPSS Statistics19.Adapun deskripsi gambaran umum responden dari penelitian ini meliputi usia, jenis kelamin, pekerjaan dan penghasilan yang digunakan sebanyak 100 orang/responden. 
Tabel 4

Demografi Responden Penelitian

\begin{tabular}{|c|c|c|}
\hline Demografi & Kategori & Frekuensi \\
\hline \multirow{4}{*}{ Usia } & dibawah 20 Tahun & 15 \\
\hline & 20 - 29 Tahun & 26 \\
\hline & 30 - 39 Tahun & 32 \\
\hline & diatas 40 Tahun & 27 \\
\hline Jenis & Laki-laki & 51 \\
\hline Kelamin & Perempuan & 49 \\
\hline \multirow[t]{4}{*}{ Pekerjaan } & PNS & 21 \\
\hline & Pengusaha & 26 \\
\hline & Karyawan Swasta & 41 \\
\hline & Wiraswasta & 12 \\
\hline \multirow[t]{5}{*}{ Penghasilan } & dibawah 3jt & 27 \\
\hline & $3 \mathrm{jt}-5 \mathrm{jt}$ & 19 \\
\hline & $5 \mathrm{jt}-7 \mathrm{jt}$ & 14 \\
\hline & $7 \mathrm{jt}-9 \mathrm{jt}$ & 7 \\
\hline & diatas $9 \mathrm{jt}$ & 33 \\
\hline \multicolumn{3}{|c|}{ Sumber: Data Olahan 2018} \\
\hline Variabel & $\begin{array}{cc}\text { Cronbanch's } & \text { Alpha } \\
\alpha & \\
\end{array}$ & Keterangan \\
\hline $\begin{array}{c}\text { Citra Merek } \\
\left(\mathrm{X}_{1}\right) \\
\end{array}$ & 0,648 & Reliabiel \\
\hline $\operatorname{Harga}\left(\mathrm{X}_{2}\right)$ & 0,727 & Reliabiel \\
\hline $\begin{array}{c}\text { Keputusan } \\
\text { Konsumen } \\
\text { (Y) }\end{array}$ & 0,657 & Reliabiel \\
\hline
\end{tabular}

\begin{tabular}{|c|c|c|c|c|}
\hline & $\begin{array}{c}\text { Pernyataan } \\
1\end{array}$ & 0,738 & 0,1966 & Valid \\
\hline$\frac{\text { Harga }}{\text { sentase }}$ & $\begin{array}{c}\text { Pernyataan } \\
2 \\
\end{array}$ & 0,747 & 0,1966 & Valid \\
\hline $15 \%(X 2)$ & $\begin{array}{c}\text { Pernyataan } \\
3 \\
\end{array}$ & 0,731 & 0,1966 & Valid \\
\hline $\begin{array}{l}20 \% \\
32 \%\end{array}$ & $\begin{array}{c}\text { Pernyataan } \\
4\end{array}$ & 0,750 & 0,1966 & Valid \\
\hline$\frac{7 \%}{51 \%}$ & $\begin{array}{c}\text { Pernyataan } \\
1 \\
\end{array}$ & 0,740 & 0,1966 & Valid \\
\hline 9Rleputusan & $\begin{array}{c}\text { Pernyataan } \\
2\end{array}$ & 0,713 & 0,1966 & Valid \\
\hline $26 \%(Y)$ & $\begin{array}{c}\text { Pernyataan } \\
3\end{array}$ & 0,671 & 0,1966 & Valid \\
\hline $\begin{array}{l}11 \% \\
2 \%\end{array}$ & $\begin{array}{c}\text { Pernyataan } \\
4 \\
\end{array}$ & 0,691 & 0,1966 & Valid \\
\hline
\end{tabular}

1Hasil Uji Reliabilitas

7\% Uji reliabilitas yaitu memiliki sifat 33\% dipercaya. Suatu alat ukur dikatakan realiabilitas, apabila dipergunakan berkali-kali oleh peneliti yang sama atau yang lain tetap akan memberikan hal yang sama. Pengujian realiabilitas dilakukan dengan menggunakan Cronbach Alpha. Jika nilai variabel valid memiliki cronbach 0,6 .

\section{Hasil Uji Validitas}

Uji Validitas digunakan untuk mengukur sah atau tidaknya suatu angket. Suatu angket dikatakan sah jika pernyataan pada angket mampu mengungkapkan sesuatu yang akan diukur oleh angket tersebut. Uji Validitas dilakukan dengan membandingkan nilai $r_{\text {hitung }}$ dengan $r_{\text {tabel }}$ untuk degree of freedom $(d f)=\mathrm{n}-\mathrm{k}$, dalam hal ini $\mathrm{n}$ adalah jumlah sampel dan $\mathrm{k}$ adalah jumlah item.

\section{Tabel 6}

\section{Uji Validitas}

\begin{tabular}{ccccc}
\hline Variabel & Pertanyaan & $\begin{array}{c}\mathbf{R} \\
\text { hitung }\end{array}$ & $\begin{array}{c}\mathbf{R} \\
\text { tabel }\end{array}$ & $\begin{array}{c}\text { Valid/ } \\
\text { tidak } \\
\text { Valid }\end{array}$ \\
\hline & $\begin{array}{c}\text { Pernyataan } \\
1\end{array}$ & 0,783 & 0,1966 & Valid \\
\cline { 2 - 4 } Citra \\
Merek & $\begin{array}{c}\text { Pernyataan } \\
2\end{array}$ & 0,685 & 0,1966 & Valid \\
\cline { 2 - 4 } (X1) & $\begin{array}{c}\text { Pernyataan } \\
3\end{array}$ & 0,686 & 0,1966 & Valid \\
\cline { 2 - 4 } & $\begin{array}{c}\text { Pernyataan } \\
4\end{array}$ & 0,691 & 0,1966 & Valid \\
\hline
\end{tabular}

\section{Hasil Uji Normalitas}

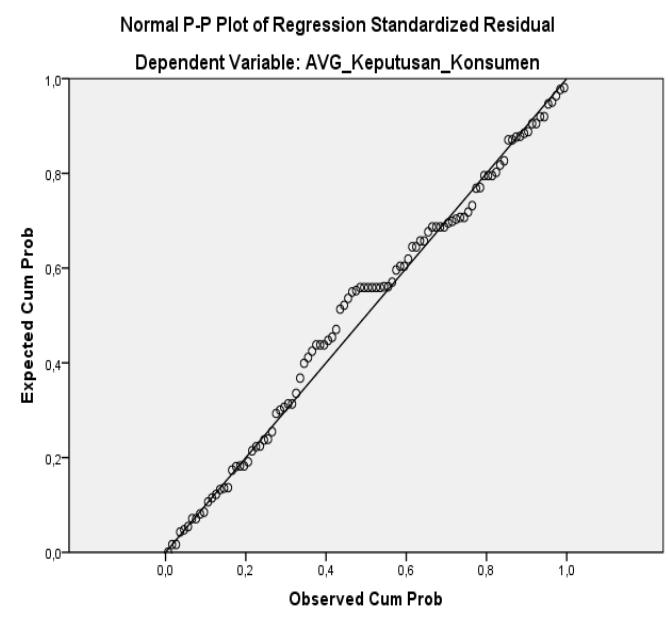

Pada Gambar diatas dapat dilihat hasil pengujian tersebut menunjukkan bahwa titik-titik berada tidak jauh dari garis diagonal. Hal ini berarti menunjukkan bahwa model regresi tersebut sudah berdistibusi normal. 


\section{Hasil Uji Heteroskedastisitas}

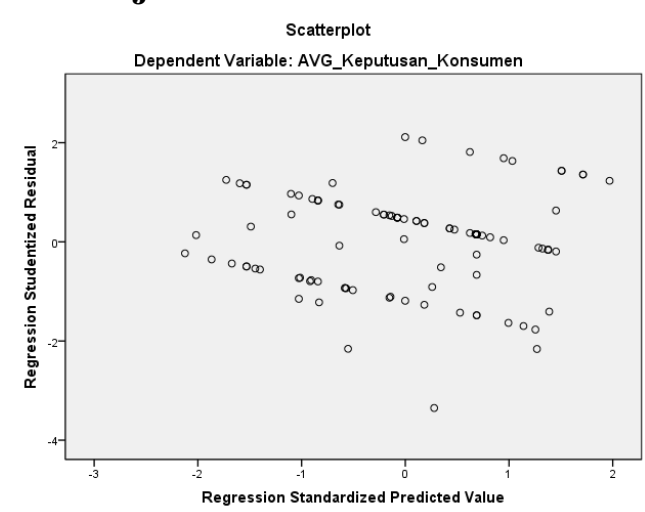

Dari Gambar di atas, terlihat bahwa hasil scatterplot dari pengujian Heteroskedastisitas menunjukan bahwa data menyebar secara acak diatas maupun di bawah angka nol pada sumbu Regression Standardized Predicted Value, artinya model regresi pada penelitian ini bebas dari gejala Heteroskedastisitas.

\section{Hasil Uji Multikolinieritas}

Berdasarkan pada tabel di atas hasil pengujian menunjukkan bahwa nilai VIF yang lebih kecil dimana semuanya berada dibawah 10 dan nilai tolerance lebih besar 0.1 . hal ini berarti bahwa variabel - variabel bebas yang digunakan dalam penelitan ini tidak menunjukkan adanya multikoliniearitas.

\section{Uji Signifikansi Simultan (Uji F)}

Tabel 7

\section{Hasil Pengujian Simultan (Uji F)}

\begin{tabular}{llll} 
& \multicolumn{3}{c}{ ANOVA $^{\mathbf{b}}$} \\
\hline \multicolumn{1}{c}{ Model } & $\mathrm{F}$ & $\mathrm{F}$ & Sig \\
& hitung & $\begin{array}{l}\text { tabel } \\
\text { tabl }\end{array}$ \\
\hline $\mathrm{X}_{1}, \quad \mathrm{X}_{2}$ & 6,452 & 3,99 & $0,001^{* * *}$ \\
terhadap & & & \\
$\mathrm{Y}$ & & &
\end{tabular}

Sumber: Data Olahan 2018

Hipotesis nol (Ho) yang digunakan dalam pengujian ini adalah tidak adanya pengaruh antara variabel independen secara bersama-sama terhadap variabel dependen.Sedangkan hipotesis alternatif (Ha) yang digunakan adalah terdapat adanya pengaruh antara variabel independen secara bersamasama terhadap variabel dependen.

Berdasarkan atas hasil tabel 7 , diperoleh hasil $\mathrm{F}_{\text {hitung }}=6,452$, dengan nilai signifikansi sebesar 0,001 . Karena $\mathrm{F}$ hitung $6,452>\mathrm{F}$ tabel 3,99 dan nilai signifikansi sebesar $0,001<0,01$, sehingga $\mathrm{H}_{1}$ diterima dan $\mathrm{H}_{0}$ ditolak yang artinya secara bersama-sama Citra Merek dan Harga secara simultan berpengaruh secara signifikan terhadap Keputusan Konsumen..

\section{Koefisien Determinasi (R2)}

Koefisien Determinasi $\quad\left(\mathrm{R}^{2}\right)$ digunakan untuk melihat kemampuan variabel indenpenden dalam menerangkan variabel dependen, dimana jika nilia $\mathrm{R}$ square mendekati 1 (satu) maka variabel independen memberikan semua informasi yang dibutukan untuk memprediksi variasi variabel dependen.

\section{Tabel 8}

Koefisien Determinasi $\left(\mathbf{R}^{2}\right)$ Model Summary ${ }^{b}$

\begin{tabular}{ccccc}
\hline MODEL & $\mathrm{R}$ & $\begin{array}{c}\mathrm{R} \\
\text { Squuare }\end{array}$ & $\begin{array}{c}\text { Adjusted } \\
\mathrm{R} \\
\text { Square }\end{array}$ & $\begin{array}{c}\text { Std } \\
\text { Error of } \\
\text { the } \\
\text { Estimate }\end{array}$ \\
\hline 1 & 0,410 & 0,168 & 0,142 & 0,61872 \\
\hline Sum
\end{tabular}

Sumber: Data Hasil Penelitian Olahan 2018

Berdasarkan pada tabel 8. diatas ini menunjukan nilai Koefisien Determinasi (Adjusted R Square) sebesar 0,142. Hal ini artinya bahwa variasi Keputusan Konsumen dijelaskan oleh-Citra Merek , Harga sebesar $\mathrm{X}_{1}, \mathrm{X}_{2}$ berpengarulk $\%$, sedangkan sisanya sebesar nilai Sig $<\alpha=0 . \%$, $8 \%$ dijelaskan variabel-variabel lainnya yang tidak diteliti

\section{Regresi Linear Berganda}

Untuk melihat seberapa besar pengaruh Citra Merek dan Harga terhadap Keputusan Konsumen maka digunakan analisis regresi liner berganda. Analisis regresi linear berganda berguna untuk menyatakan hubungan kausalitas antara variabel 
bebas dengan variabel terikat. Model hubungan nilai karyawan dengan variabel-variabel tersebut dapat disusun dalam fungsi atau persamaan sebagai berikut

Tabel 9

Regresi Linier Berganda

\begin{tabular}{llcc}
\hline Model & \multicolumn{2}{l}{$\begin{array}{l}\text { Unstandardized } \\
\text { Coeffcients }\end{array}$} & $\begin{array}{l}\text { Standardized } \\
\text { Coeffcients } \\
\text { Beta }\end{array}$ \\
\cline { 2 - 3 } $\mathrm{B}$ & Std.Error & \\
\hline (Counstant) & 0,986 & 0,690 & \\
\hline Produk $\left(\mathrm{X}_{1}\right)$ & 0,071 & 0,114 & 0,059 \\
\hline Harga $\left(\mathrm{X}_{2}\right)$ & 0,419 & 0,121 & 0,325 \\
\hline
\end{tabular}

Sumber: Data Olahan,2018.

Berdasarkan pada tabel 8 di atas, maka persamaan regresi liniear berganda dalam penelitian ini adalah : $\mathrm{Y}=0,986+0,071 \quad \mathrm{X}_{1}+0,419 \mathrm{X}_{2}+\mathrm{e}$ Persamaan regresi linier berganda di atas dapat dijelaskan sebagai berikut : (1) Dari regresi linier berganda tersebut diperoleh nilai konstanta $(\alpha)$ sebsar 0,986 yang artinya apabila Citra Merek, Fitur dan Harga nilainya adalah 0, maka Keputusan Konsumen nilainya adalah 0,986 satuan. (2) Nilai koefisen regresi linier berganda variabel Citra Merek sebesar 0,071 yang berarti jika variabel independen lainya tetap dan Citra Merek mengalami kenaikan 1 satuan, maka Keputusan Konsumen akan mengalami kenaikan sebesar 0,071 satuan. Koefisen bernilai positif artinya terjadi hubungan positif, dimana Citra Merek yang tinggi akan meningkatkan Keputusan Konsumen. (3) Nilai koefisen regresi linier berganda variabel Harga sebesar 0,419 yang berarti jika variabel independen lainya tetap dan Harga mengalami kenaikan 1 satuan, maka Keputusan Pembelian akan mengalami kenaikan sebesar 0,419 satuan. Koefisen bernilai positif artinya terjadi hubungan positif, dimana Harga yang tinggi akan meningkatkan Keputusan Pembelian

\section{Uji Parsial (Uji t)}

Uji $\mathrm{t}$ digunakan untuk menguji signifikansi hubungan antara variable $\mathrm{X}$ dan variabel $Y$. Berikut adalah hasil perhitungan uji $t$ :

Tabel 10

Hasil Uji Parsial ( Uji t )

\begin{tabular}{ccccl}
\hline Model & $\mathrm{T}_{\text {hitung }}$ & $\mathrm{T}_{\text {tabel }}$ & Sing & Keterangan \\
\hline $\begin{array}{c}\text { Citra } \\
\text { Merek }\end{array}$ & & & & Tidak \\
$\left(\mathrm{X}_{1}\right)$ & 0,627 & 1,2903 & $0,532^{*}$ & $\begin{array}{l}\text { Berpengaruh } \\
\text { signifikan }\end{array}$ \\
\hline $\begin{array}{c}\text { Harga } \\
\left(\mathrm{X}_{2}\right)\end{array}$ & 3,447 & 2,3654 & $0,001^{* * *}$ & $\begin{array}{l}\text { Berpengaruh } \\
\text { signifikan }\end{array}$ \\
\hline
\end{tabular}

Sumber: Data Olahan, 2018.

Berdasarkan pada tabel 10

diatas, maka hasil pengujian secara parsial dapat dijelaskan sebagai berikut : (1) Pengaruh Citra Merek terhadap Keputusan Pembelian, Artinya hasil pengujian menunjukkan bahwa nilai $\mathrm{T}$ hitung untuk variabel Citra Merek sebesar $0,627<$ dari $\mathrm{T}_{\text {tabel }}$ sebsar 1,2903 atau nilai signifikan $0.532>$ dari alpha 0,1 . maka $\mathrm{H}_{1}$ ditolak, dengan berarti bahwa tidak berpengaruh \&signifikan terhadap Keputusan Pembelian. (2) Pengaruh Harga terhadap Keputusan Pembelian, Artinya hasil pengujian menunjukkan bahwa nilai $\mathrm{T}$ hitung untuk variabel Harga sebesar 3,447 > dari $\mathrm{T}_{\text {tabel }}$ sebesar 2,3654 atau nilai signifikan 0.001 < dari alpha 0,01. maka $\mathrm{H}_{3}$ diterima, dengan berarti bahwa berpengaruh \&signifikan terhadap Keputusan Pembelian.

\section{Pengaruh Citra Merek terhadap Keputusan Pembelian}

Hasil analisis secara deskriptif memunjukkan bahwa variabel Citra Merek merupakan variabel yang memiliki penilaian yang baik dari konsumen analisis deskriptif diketahui bahwa hasil pengujian regresi linear berganda dan hasil pengujian parsial (uji t). Dari pengujian regresi menunjukkan pengaruh yang positif dari variabel Citra Merek terhadap Keputusan Pembelian, dan dari hasil pengujian parsial menunjukkan citra merek tidak berpengaruh yang signifikan terhadap Keputusan 
Pembelian. Dengan demikian, apabila Asia Ponsel Pekanbaru meningkatkan Citra Merek maka Keputusan Pembelian. Juga akan mengalami peningkatan yang signifikan.

Merek merupakan janji penjual untuk secara konsisten memberikan fitur, manfaat, dan jasa tertentu kepada pembeli, bukan hanya sekedar simbol yang membedakan produk perusahaan tertentu dengan kompetitornya . Kotler dan Amstrong (2008) mempunyai pendapat bahwa merek merupakan nama, istilah, tanda, simbol, desain atau kombinasi yang ditujukan untuk mengidentifikasi barang atau jasa yang ditawarkan perusahaan sekaligus sebagai diferensiasi produk.

Hasil penelitian ini menunjukkan bahwa Citra Merek tidak berpengaruh signifikan terhadap Keputusan Pembelian Asia Ponsel Pekanbaru.Dimana hasil yang diperoleh ini tidak sejalan dengan hasil penelitian yang dilakukan oleh (Siti Hamidah 2013), (Aditya Yessika Alena 2013) dan (Maria Dewi Ratnasari 2014) disimpulkan bahwa terdapat pengaruh Citra Merek terhadap keputusan Pembelian.

\section{Pengaruh Harga terhadap Keputusan Pembelian}

Hasil analisis secara deskriptif memunjukkan bahwa variabel Harga merupakan variabel yang memiliki penilaian yang sangat baik dari konsumen dengan rata-rata skor 4,07. analisis deskriptif diketahui bahwahasil pengujian regresi linear berganda dan hasil pengujian parsial (uji t). Dari pengujian regresi menunjukkan pengaruh yang positif dari variabel Harga terhadap Keputusan Pembelian, dan dari hasil pengujian parsial menunjukkan adanya berpengaruh yang signifikan terhadap Keputusan Pembelian. Dengan demikian, apabila Asia Ponsel Pekanbaru meningkatkan
Harga maka Keputusan Pembelian Juga akan mengalami peningkatan yang signifikan.

Harga adalah sejumlah uang yang ditagihkan atas suatu produk dan jasa atau jumlah dari nilai yang ditukarkan para pelanggan untuk memperoleh manfaat dari memiliki atau menggunakan suatu produk dan jasa. (kotler dan amstrong, 2012). Harga merupakan satuan moneter atau ukuran lainnya (termasuk barang atau jasa lainnya) yang ditukarkan agar memperoleh hak kepemilikan atau penggunaan suatu barang atau jasa. Harga merupakan komponen yang berpengaruh langsung terhadap laba perusahaan. Tingkat harga yang ditetapkan mempengaruhi kuantitas yang terjual. Selain itu secara tidak langsung harga juga mempengaruhi biaya, karena kuantitas yang terjual berpengaruh pada biaya yang ditimbulkan dalam kaitannya dengan efisiensi produksi. Untuk pelanggan yang sensitif terhadap harga, harga yang murah biasanya adalah sumber kepuasan yang penting karena pelanggan akan mendapatkan value for money yang tinggi.

$\begin{array}{ccr}\text { Hasil } & \text { penelitian } & \text { ini } \\ \text { menunjukkan } & \text { bahwa } & \text { Harga }\end{array}$ berpengaruh signifikan terhadap Keputusan Pembelian Asia Ponsel Pekanbaru Pekanbaru. Dimana hasil yang diperoleh ini tidak sama dengan hasil penelitian Syaleh (2017) dan Santoso (2018) yang menyatakan bahwa Harga berpengaruh signifikan terhadap Keputusan Pembelian.

\section{PENUTUP \\ Kesimpulan}

Berdasarkan pada hasil analisis regresi linier berganda yang telah dilakukan pada penelitian ini, maka dapat ditarik kesimpulan bahwa : (1) harga berpengaruh terhadap Keputusan 
Pembelian Asia Ponsel Pekanbaru (2) citra merek tidak berpengaruh terhadap Keputusan Pembelian Asia Ponsel Pekanbaru.

\section{Saran}

Berdasarkan hasil penelitian dan evaluasi, maka saran yang dapat diberikan adalah sebagai berikut : (1) Bagi Asia Ponsel Pekanbaru, untuk meningkakan Citra Merek, Asia Ponsel Pekanbaru harus meningkatkan reputasi yang baik dikalangan masyarakat dan untuk meningkatkan Harga Asia Ponsel Pekanbaru harus meningkatkan harga yang sesuai dan bermanfaat yang ada pada Smartphone Xiaomi. (2) Bagi Akademis, hasil dari penelitian ini dapat dijadikan sebagai penambah referensi oleh pihak lain yang melakukan penelitian untuk permasalahan yang sama dimasa yang akan datang, dan bagi peneliti selanjutnya diharapkan dapat menambah variabel lain diluar variabel yang sudah diteliti dalam penelitian ini agar memperoleh hasil yang bervariasi yang dapat berpengaruh terhadap kepuasan pembelian.

\section{DAFTAR RUJUKAN}

Adirama, Aldi. (2012). Pengaruh Citra Merek dan Kualitas Produk terhadapKeputusan Pembelian Konsumen Motor Satria FU di Klaten. Jurnal Manajemen Bisnis Indonesia, Vol.1, Edisi I. Yogyakarta: Universitas Negeri Yogyakarta.

Alma, Buchari, (2009). Manajemen Pemasaran dan pemasaran jasa. Bandung: alfabeta.

Bernadette, Jilly Mandey. (2013). Promosi Distribusi Harga Pengaruhnya terhadap Keputusan Pembelian Rokok Surya Promild. Jurnal EMBA. 1(4) Desember 2013, 95-104
Daryanto. (2013). Sari Kuliah Manajemen Pemasaran (cetakan 2). Bandung. Penerbit: PT Sarana Tutorial Nurani Sejahtera.

Guntur, Effendi, M. (2010). Transformasi Manajemen Pemasaran Membangun Citra Negara. Sagung Seto, Jakarta.

Hamidah Siti. (2013). Analisis persepsi citra merek, desain, fitur dan pengaruhnya terhadap keputusan pembelian produk handphone samsung berbasis android (studi kasus STIE Pelita Indonesia). Jurnal ekonomi STIE Pelita Indonesia. 21 (1):89-120

Kotler dan Amstrong. (2008). manajemen pemasaran. In edisi 12 jilid 2. Jakarta: Indeks.

Kotler dan Keller. (2009). Manajemen Pemasaran. Jilid I. Edisi ke 13 Jakarta: Erlangga

Kotler, Philip. (2010). Manajemen Pemasaran. Edisi tiga belas Bahasa Indonesia.Jilid 1 dan 2.Jakarta : Erlangga.

Kotler, dan Keller. (2012). Manajemen Pemasaran. Edisi 12. Jakarta: Erlangga

Kotler Philip dan Amstrong. (2012). prinsip - prinsip manajemen. In edisi 14 jilid 1. Jakarta: erlangga.

Maria Dewi Ratnasari (2014), tentang Pengaruh Citra merek dan kualitas produk terhadap proses keputusan pembelian blackberry (Diponegoro journal of social and politic tahun 2014)

Santoso, P. H. (2018). Analisis Pengaruh Harga, Citra Merek, dan Kredibilitas Perusahaan terhadap Niat Membeli Konsumen pada Produk Kawasaki di Kota Yogyakarta. Journal of Economic, Bussines and Accounting (COSTING), 1(2), 209-220. doi:10.31539/costing.v1i2.208 
Stanton, William J. (2008). Fundamental of Marketing. 10

Edition. Mc. Graw-Hill International Edition, New York.

Sugiyono. (2010). Metode Penelitian Pendidikan (Metode Penelitian KuantitatifKualitatif Dan $R \& D$ ). Bandung: Alfabeta.

Syaleh, H. (2017). Pengaruh Kualitas Produk, Harga, Promosi dan Tempat Pendistibusian Terhadap Keputusan Pembelian Sepeda Motor Yamaha Pada Perusahaan Tjahaja Baru Bukittinggi. Journal of Economic, Bussines and Accounting (COSTING), 1(1), 6882. doi:10.31539/costing.v1i1.16

Tjiptono, Fandi. (2010), Strategi pemasaran, Edisi 2, Andi offset, Yogyakarta

Wibowo. (2012). Manajemen Kinerja. Jakarta : Raja Grafindo Persada 